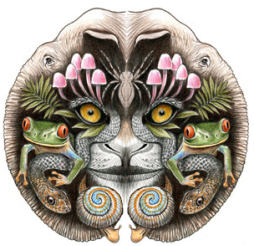

ISSN

Online 0974-7907

Print 0974-7893

OPEN ACCESS

\title{
COMPARISON OF INSECT BIODIVERSITY BETWEEN ORGANIC AND CONVENTIONAL PLANTATIONS IN KODAGU, KARNATAKA, INDIA
}

\author{
Shamika Mone ${ }^{1}$, K.M. Kusha ${ }^{2}$, Devcharan Jathanna ${ }^{3}$, Musthak Ali $^{4}$ \& Anurag Goel $^{5}$ \\ ${ }^{1}$ OFAI - Organic Farming Association of India, G-8 St. Britto's Apts, Mapusa, Goa 403507, India \\ ${ }^{2}$ 120/121 Dharani Nilaya, Manganahalli, Jnanabharathi, Bengaluru, Karnataka 560056, India \\ ${ }^{3}$ Centre for Wildlife Studies, CWS, Bengaluru, Karnataka, India \\ ${ }^{4}$ UAS - University of Agricultural Sciences, GKVK Campus, Bengaluru, Karnataka 560065, India \\ ${ }^{5}$ WAPRED - Worldwide Association for Preservation and Restoration of Ecological Diversity, \\ P.O. Box-101, Madikeri, Kodagu, Karnataka 571201, India \\ ${ }^{1}$ shamikamone@gmail.com, ${ }^{2}$ kusha.km.85@gmail.com, ${ }^{3}$ devcharan@gmail.com, \\ ${ }^{4}$ ali.musthak@gmail.com, ${ }^{5}$ annugoel@gmail.com (corresponding author)
}

Abstract: We undertook a comparative analysis of ground insects and fruit eating butterflies on 29 different plantations in Kodagu District of Karnataka which is one of the rich biodiversity zones of the Western Ghats. These included organic and conventional coffee and cardamom plantations using different levels of chemical fertilizers and pesticides. A total number of 457 ground insect species were collected using pit-fall traps which included 92 species of ants and 123 species of beetles, among other insect taxa that we measured. Similarly, 25 species of butterflies belonging to the family Nymphalidae were collected using bait traps. We found a clear negative effect on the ground insect species diversity (Shannon index) and evenness (Shannon evenness index) in pesticide treated plantations as compared to the organic plantations. A similar negative effect was observed for butterfly diversity in plantations using pesticides. Our results corroborate the value of organic plantations in supporting higher levels of biodiversity.

Keywords: Biodiversity, cardamom, coffee, conservation, insects, organic agriculture, pesticides, Western Ghats.

DOI: http://dx.doi.org/10.11609/JoTT.03778.6186-94

Editor: Shonil A Bhagwat, The Open University, UK

Date of publication: 26 August 2014 (online \& print)

Manuscript details: Ms \# 03778 | Received 19 September 2013 | Final received 30 June 2014 | Finally accepted 20 July 2014

Citation: Mone, S., K.M. Kusha, D. Jathanna, M. Ali \& A. Goel (2014). Comparison of insect biodiversity between organic and conventional plantations in Kodagu, Karnataka, India. Journal of Threatened Taxa 6(9): 6186-6194; http://dx.doi.org/10.11609/JoTT.o3778.6186-94

Copyright: (c) Mone et al. 2014. Creative Commons Attribution 4.0 International License. JoTT allows unrestricted use of this article in any medium, reproduction and distribution by providing adequate credit to the authors and the source of publication.

Funding: We are indebted to The Third World Network (TWN), Malaysia, for their financial support for this study.

Competing Interest: The authors declare no competing interests.

Author Contribution: SM led field team, performed statistical analysis of data, contributed to writing of paper: KMK assisted with fieldwork; DJ was involved at all stages of project, especially initial design, statistical analysis, and manuscript preparation; MA identified all the ant species and discussed the relevance of the data; AG supervised the research plan and implementation of the field work and wrote up the paper.

Author Details: SHAMIKA MONE, MSc., Research director with Organic Farmers' Association of India (OFAI), Goa. K.M. KuSHA, M.Sc., presently employed with M/s. Metamorphosis Project Consultants Pvt Ltd., Bangalore. DeVChARAN JATHAnNA, Senior Research Associate at Centre for Wildlife Studies, Bangalore, MusthaK AL Retired Professor of Entomology from UAS, Bangalore, expert myrmecologist and still very active in trailing ants across India. ANURAG GOEL, PhD, Research Scientist and Naturalist, co-founding director of ngo, WAPRED. Presently documenting biodiversity at Mojo Plantation, Galibeedu, Madikeri, Kodagu District, Karnataka.

Acknowledgements: We are indebted to the Organic Farming Association of India (OFAl) without which this study could not have been implemented. We thank Prof. Viraktamath, University of Agricultural Sciences, Bangalore for his generous time and expertise in identifying the enormous collection of insects. We also thank our field assistant Arun Kumar and Aathira Perinchery (National Centre for Biological Sciences, NCBS), Navendu Page and Samira Agnihotri (Centre for Ecological Sciences, CES) for their unstinting help in identifying the butterflies, plants and bird calls, respectively. We thank Dr. Sujata Goel, Maya Goel, Archana Shetty and all the interns at Rainforest Retreat for their ever helpful support. Many thanks go to Rutuja Kate, Meera and Meghana who helped us out with the R language. Finally, we are grateful to the land owners who allowed us access to their plantations in order to conduct this study. 


\section{INTRODUCTION}

Agriculture is a dominant human activity and occupies about $40 \%$ of available land space globally (World Development Indicators online database, World Bank), even more in India (World Bank Report 2010). Therefore, the decisions that farmers make can dramatically affect biodiversity at all taxonomic levels. Modern farming practices (mechanization, monocropping, hybrid varieties and genetically modified GM crops) combined with the heavy use of agri-chemicals (fertilizers, pesticides and herbicides) have resulted in a loss of biodiversity in agricultural landscapes and surrounding areas (Andow 1983; Altieri \& Letourneau 1984; Fuller et al. 1995; Krebs et al. 1999; Stoate et al. 2001; Benton et al. 2002, 2003). Agricultural ecosystems that are rich in biodiversity possess greater resilience and are, therefore, able to recover more readily from biotic and abiotic stresses such as drought, environmental degradation, pests, diseases, epidemics, among others (Wilsey \& Polley 2002; Wittebolle et al. 2009). Clearly, higher community evenness-as found on organic plantations (Crowder et al. 2010)-enhances resistance to invasion and other forms of functionality under stress (Wilsey \& Polley 2002; Wittebolle et al. 2009). Further, biodiversity conservation in agricultural landscapes also promotes higher species richness (Bengtsson et al. 2005) and facilitates metapopulation processes between habitat patches (Perfecto \& Vandermeer 2010).

Insects have co-evolved with plants for millions of years and are of enormous importance for agriculture. Some insects can damage crops, but others also provide pollination and pest control services, or improve the fertility of the soil through feeding on and assisting the decomposition of organic matter. Conventional agricultural pest-management practices often lead to altered community structure (Macfadyen et al. 2009) and communities dominated by a few species, which contributes to pest outbreaks. Organic farming methods mitigate this ecological damage by promoting evenness among natural enemies (Crowder et al. 2010) which then contributes to a pest-predator balance. Hence, species evenness was considered an important response variable in the present study. While many studies in Europe, Australia and Mexico (Bengtsson et al. 2005; Horne 2007; MacFadyen et al. 2009) have demonstrated that organic plantations support a greater level of insect diversity, such studies are lacking in tropical zones which harbour similar biodiversity. Studies on biodiversity in coffee plantations in the Western Ghats have examined bird, mammal and butterfly diversity (Bali et al. 2007; Dolia et al. 2007; Anand et al. 2008) in plantations at varying distances from forests, but have not compared organic and conventional plantations. This study attempts to fill this gap in our understanding of agricultural systems by comparing ground insect biodiversity in organic and conventional plantations.

\section{STUDY AREA AND METHODS}

This study was carried out in the cardamom and coffee plantations of Kodagu District of Karnataka state, situated in the Western Ghats of southern India. The average annual rainfall in the area ranges from 1500-4000 mm and most of it occurs during the southwest monsoon between June and September. The temperature ranges from a minimum of $11^{\circ} \mathrm{C}$ in winters to a maximum of $28^{\circ} \mathrm{C}$ in summers. The natural vegetation cover is evergreen forest, which remains in the study landscape as fragments at varying levels of degradation. Both cardamom and coffee are cultivated under a two-tier mixed shade canopy comprising leguminous and non-leguminous evergreen shade trees. Coffee requires about $40 \%$ shade whereas cardamom requires $60 \%$ shade (Anonymous 1985). Therefore, in mixed systems coffee is generally grown on slopes with pepper as an intercrop while cardamom is grown in the moist valleys.

We selected 29 plots in different parts of Kodagu District (Fig. 1). These included 12 in completely organic plantations that apply no pesticides or chemical fertilizers, five in plantations using only chemical fertilizers (NPK) but not pesticides, and 12 in conventional plantations that used NPK as well as chemical pesticides. Most (but not all) of the organic plantations had been certified by an international agency for an average of six years and conventional plantations had varying levels of pesticide use. We had originally intended to sample using the powerful randomised block design (Quinn \& Keough 2002), but had to abandon this during the course of the study since we were unable to find clearly and meaningfully definable blocks. Because of this, pairs of plantations of different types (organic and conventional) are sometime located close together. However, we are confident that the overwhelming effect of treatments will justify statistical independence in such cases. The minimum distance between plantations of the same type is $1 \mathrm{~km}$. We collected ground insects and butterflies from the months April to May (before the onset of the monsoons) followed by collection from the months October to March (following the monsoon rains). 


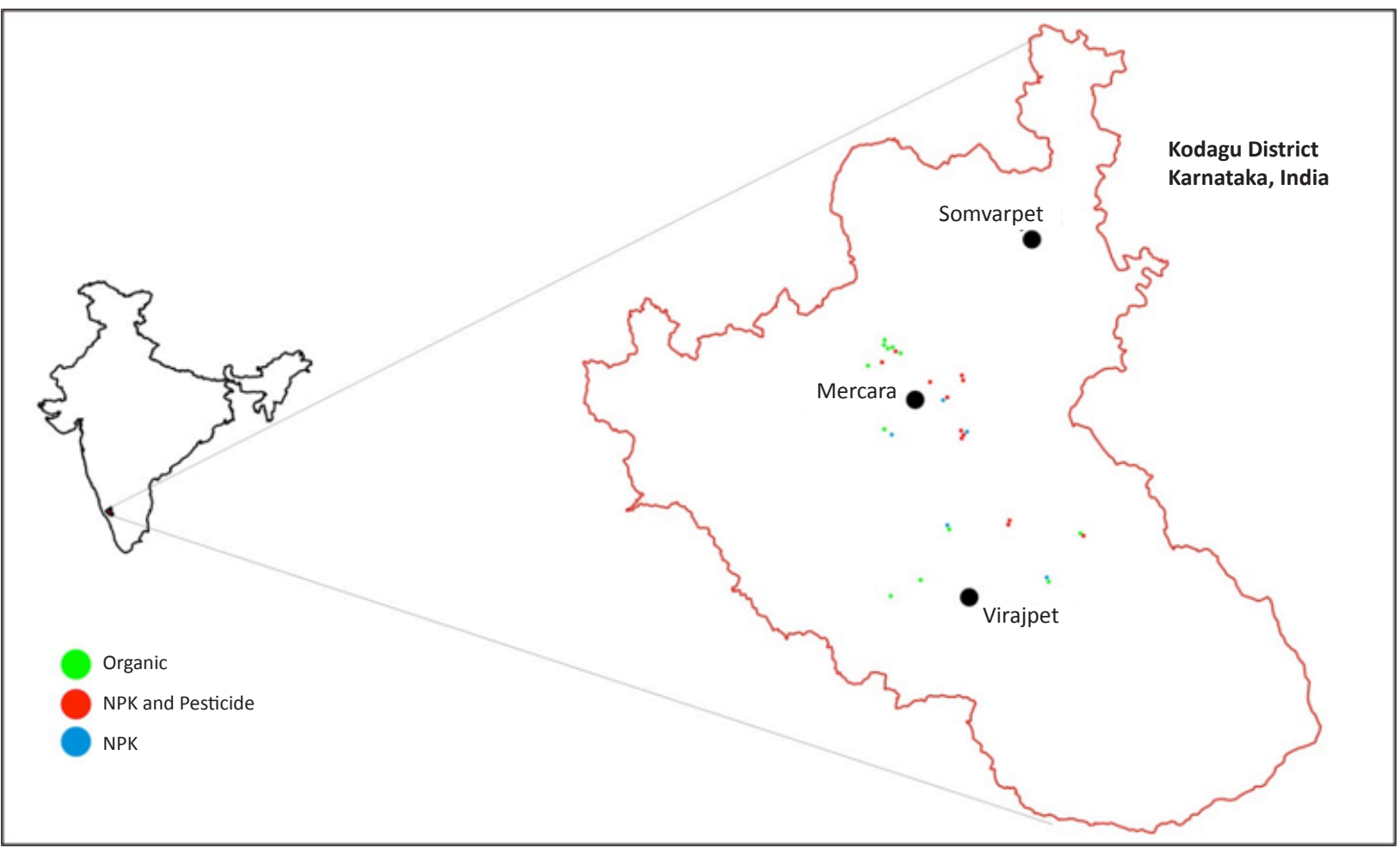

Figure 1. Location of sampled plots within Kodagu District, Karnataka, India. Inset shows location of Kodagu within India.

Wherever possible, one organic and one conventional plot were monitored simultaneously, as explained above.

Pitfall traps were used to capture ground-foraging insects. A 1.21 to 2.02 ha (3-5 acre) plot was selected on each plantation. The plot was selected by the field team so as to cover a representative part of the estate but also to ensure no edge effects from neighbouring plantations that may have been of a different type (e.g., pesticide runoff into an organic plantation, effects due to spatial dependence in the response variable). In each plot, five equally spaced transect lines $20 \mathrm{~m}$ apart were demarcated with string and mapped using a global positioning system (GPS). Each transect measured 40m in length and five pitfall traps were placed $10 \mathrm{~m}$ apart on each transect. Hence, a total of 20 pitfall traps were placed in each plot. Each pitfall trap consisted of a plastic disposable cup, measuring about $10 \mathrm{~cm}$ in height and $6 \mathrm{~cm}$ in diameter. The cups were buried at ground level and protected from rain by a plastic plate at a distance of about $2 \mathrm{~cm}$ above the ground. Each cup contained $15 \mathrm{ml}$ of ethanol (50\%) and 2-3 drops of glycerine to prevent evaporation. Trap contents were collected every $24 \mathrm{~h}$ over four consecutive days, and preserved in ethanol (70\%) before identification. Ants were separated from other insects for the purpose of identification.
We surveyed fruit-feeding butterflies using hanging traps baited with over-ripe, fermenting fruits (banana, apple, papaya). Each trap consisted of a cylindrical net with a conical head and a wooden plank hanging $2.5 \mathrm{~cm}$ below the bottom of the net. The bait dish was placed on the wooden plank so that any butterflies visiting the bait were trapped within the net as they flew upwards. Three traps were randomly placed (equidistant from each other, approximately $30 \mathrm{~m}$ apart) in the same plot used for the pitfall traps. The traps were emptied and the bait replaced every 24 hours over four consecutive days. The trapped butterflies were photographed, counted and released. The photographed butterflies were then identified using a field guide on butterflies of India (Kehimkar 2008).

Total ground insects and butterflies were identified to the lowest possible taxonomic level. These data were used to estimate mean species richness (not shown here), mean Shannon's diversity (which takes into account both species richness and evenness) and mean Shannon's evenness (data shown as evenness for each pitfall trap cumulative over four days. Evenness data is shown as it is considered an important response variable for effective pest control on organic farms (Crowder et. al. 2010).

The data were analysed using linear modelling (Quinn 
\& Keough 2002) in conjunction with a model selection approach (Burnham \& Anderson 2002; Johnson \& Omland 2004). We chose the model selection approach over the traditional null hypothesis testing as our data were derived from an observational study which lacked randomization of treatments and controls. We carried out separate analyses for the different response variables (species richness, diversity and evenness), using linear models with treatment (three levels: organic, NPK, pesticide) and crop type (cardamom or coffee) as the categorical predictors. We fitted models where the response variable was a function of only crop, only treatment, the additive effect of crop and treatment and the interaction between crop and treatment. The trap data were combined to the level of the plot (=estate) prior to statistical analyses, so random effects were not included in the models. Further, plantations were classified into four categories as $\mathrm{OP}$, $1 \mathrm{P}, 2 \mathrm{P}$ and $3 \mathrm{P}$ depending on the number of different pesticides used per year. (OP - No pesticide or NPK; 1P - 1-3 pesticide applications; 2P - 4-7 applications; 3P 8-14 applications). All statistical analysis was carried out using the statistical programming package $R(R$ Development Core Team 2008).

\section{RESULTS}

\section{Pitfall traps}

Total Ground Insects: Diversity: A total of 32,484 ground insects belonging to 467 different species, including 92 ant species and 123 beetle species, were collected using pitfall traps. The effect of treatment on the species diversity index was observed to be the best fit model (Table 1). Shannon's species diversity index $\left(H^{\prime}\right)$ is clearly higher in organic (G) plantations compared to pesticide $(\mathrm{P})$ plantations, while diversity in NPK (N) plantations overlaps with that of other treatments (Fig. 1). The role of treatment in determining Shannon's species diversity index $\left(\mathrm{H}^{\prime}\right)$ received further support from the next best model which included the additive effects of treatment and crops. ( $\triangle A I C=1.19$; Table 1). Here we see that there is a clear negative effect of pesticide treatment on Shannon's species diversity index $\left(\mathrm{H}^{\prime}\right)$ when compared with organic plantations in both coffee and cardamom plantations. There is no discernible effect of treatment on Shannon's species diversity index $\left(\mathrm{H}^{\prime}\right)$ in NPK plantations (Fig. 2).

Total ground insects: Evenness: The additive effect of crop and treatment on the Shannon's species evenness index (E) was observed to be the best fit model (Table 2). Shannon's species evenness index (E) is clearly higher in organic (G) plantations compared to pesticide (P) plantations (Fig. 3). The role of treatment in determining Shannon's species evenness index (E) received further support from the next best model which included only treatment $(\triangle A I C=1.36$; see Table 1 and Fig. 3 ). The evenness index for NPK (N) plantations is intermediate, overlapping both organic and pesticide plantations.

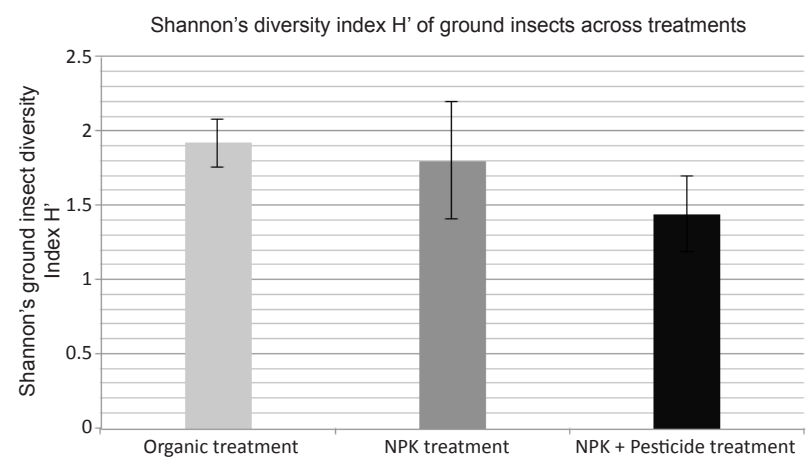

Figure 2. Bar plot for ground insects shows the mean Shannon's diversity index $\mathrm{H}^{\prime}$ for all treatments with their $95 \%$ confidence intervals (Cl). Note the $95 \% \mathrm{Cl}$ for treatments organic (G) and NPK + pesticide $(\mathrm{P})$ do not overlap.
Table 1. Model selection results for factors affecting diversity of overall ground insects and nymphalid butterflies. The best model is included in boldface font.

\begin{tabular}{|c|c|c|c|c|}
\hline $\begin{array}{c}\text { Shannon's Diversity } \\
\text { Index (H') }\end{array}$ & \multicolumn{2}{|c|}{$\begin{array}{c}\text { Pitfall trap (Ground } \\
\text { insects) }\end{array}$} & \multicolumn{2}{c|}{$\begin{array}{c}\text { Bait trap (Nymphalid } \\
\text { butterflies) }\end{array}$} \\
\hline & $\Delta$ AIC & $\begin{array}{c}\text { AIC } \\
\text { weight }\end{array}$ & $\Delta$ AIC & $\begin{array}{c}\text { AIC } \\
\text { weight }\end{array}$ \\
\hline Treatment & 0.0 & 0.569 & 0.0 & 0.665 \\
\hline Crop & 6.885 & 0.018 & 6.620 & 0.024 \\
\hline Crop + Treatment & 1.198 & 0.312 & 1.788 & 0.272 \\
\hline Crop * Treatment & 3.485 & 0.099 & 5.716 & 0.038 \\
\hline
\end{tabular}

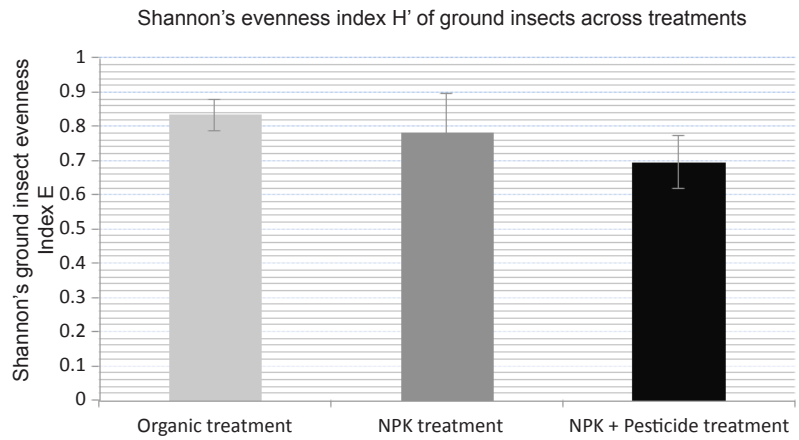

Figure 3. Bar plot for ground insect shows mean Shannon's species evenness index (E) for all treatments with their $\mathbf{9 5 \%}$ confidence intervals $(\mathrm{Cl})$. 
Table 2. Model selection results for factors affecting evenness of overall ground insects and nymphalid butterflies. The best model is included in boldface font.

\begin{tabular}{|c|c|c|c|c|}
\hline $\begin{array}{c}\text { Shannon's } \\
\text { Evenness Index (E) }\end{array}$ & \multicolumn{2}{|c|}{$\begin{array}{c}\text { Pitfall trap (Ground } \\
\text { insects) }\end{array}$} & \multicolumn{2}{c|}{$\begin{array}{c}\text { Bait trap (Nymphalid } \\
\text { butterflies) }\end{array}$} \\
\hline & $\Delta$ AIC & $\begin{array}{c}\text { AIC } \\
\text { weight }\end{array}$ & $\Delta$ AIC & $\begin{array}{c}\text { AIC } \\
\text { weight }\end{array}$ \\
\hline Treatment & 1.366 & 0.292 & 0.0 & 0.478 \\
\hline Crop & 7.175 & 0.016 & 0.976 & 0.293 \\
\hline Crop + Treatment & 0.0 & 0.579 & 1.960 & 0.179 \\
\hline Crop * Treatment & 3.303 & 0.111 & 4.588 & 0.048 \\
\hline
\end{tabular}
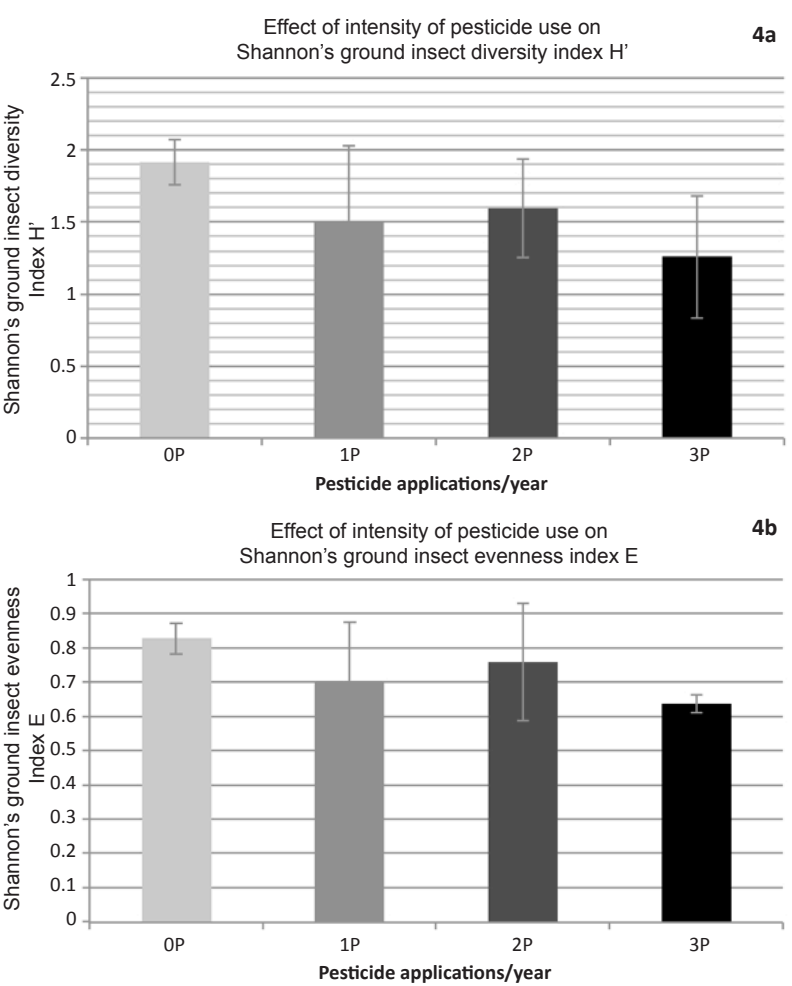

Figure 4. The bar graph shows the effect of increase in chemical pesticides on ground insect species diversity (Fig. 4a) and evenness (Fig. 4b) with their $95 \%$ confidence intervals (CI).

Effect of chemical pesticides on ground insect species diversity and evenness indices: Clear differences were seen in Shannon's species diversity index $\left(\mathrm{H}^{\prime}\right)$ (Fig. $4 a)$ between pesticide-free (OP) plantations and heavily sprayed (3P) plantations (95\% confidence interval $[\mathrm{Cl}]$ for pesticide free (OP) and heavily sprayed (3P) do not overlap).

Similar results were observed for Shannon's species evenness index $\left(\mathrm{H}^{\prime}\right)$ (Fig. 4b) where there is a clear difference between pesticide-free (OP) plantations and heavily sprayed (3P) plantations.
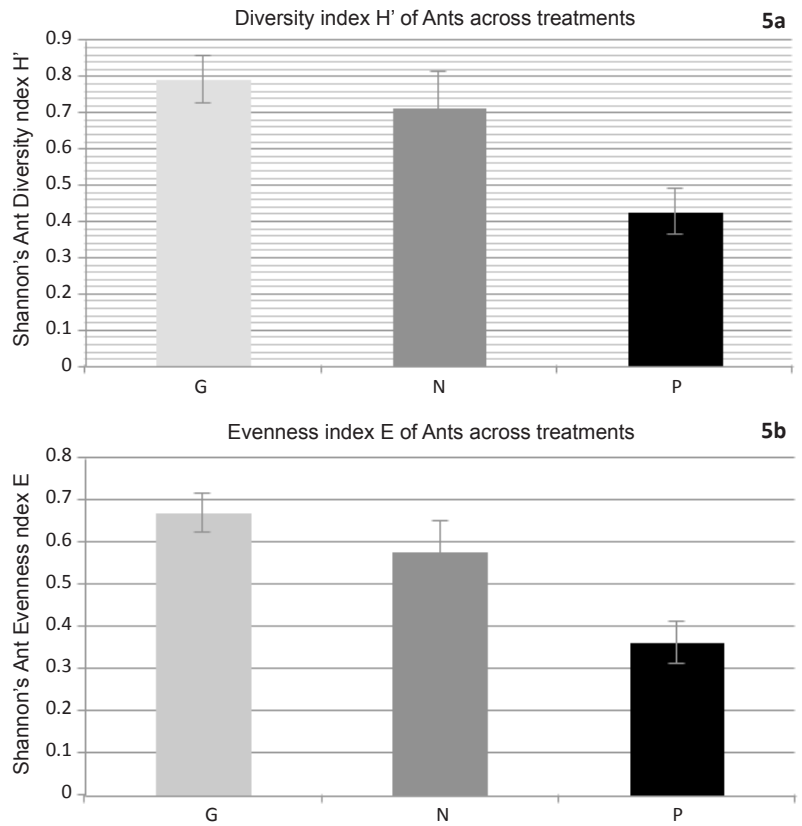

Figure 5a. Bar plot for ant species shows the mean Shannon's diversity index $\mathrm{H}^{\prime}$ for all treatments with their $\mathbf{9 5 \%}$ confidence intervals $(\mathrm{Cl})$; Figure $5 \mathrm{~b}$. Bar plot for ant species shows mean Shannon's evenness index $\mathrm{E}$ for all treatments with their $95 \%$ confidence intervals $(\mathrm{Cl})$. Note the $95 \% \mathrm{Cl}$ of treatments organic (G) and NPK + pesticide (P) do not overlap in either plot.
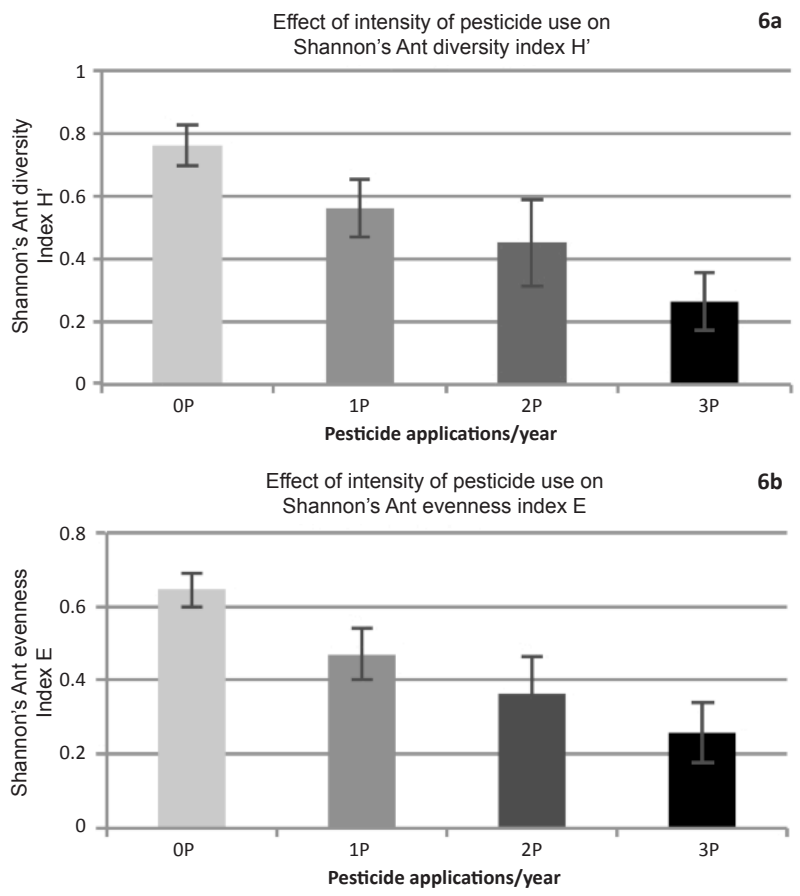

Figure 6. Bar plot shows the effect of increase in chemical pesticides on ant species diversity (Fig. 6a) and evenness (Fig. 6b) indices with their $95 \%$ confidence intervals $(\mathrm{Cl})$. 


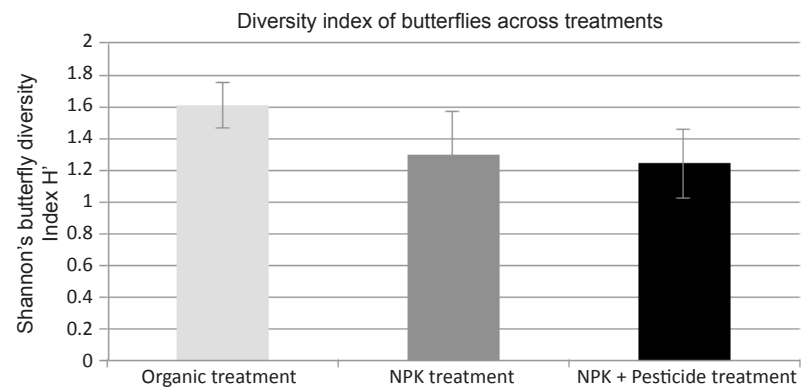

Figure 7. Bar plot for butterflies shows mean Shannon's diversity index values ' $\mathrm{H}^{\prime}$ for all treatments with their $95 \%$ confidence intervals $(\mathrm{Cl})$.

\section{Pitfall Traps}

Ants: Diversity and Evenness: A total of 6695 ants comprising 92 species were collected from the pitfall traps. Similar to overall ground insect data, we analysed patterns for just ants by fitting and comparing the same set of models. The results for ant species diversity and evenness are similar to those obtained for all ground insects and they confirm that pesticide treatment (P) has a considerable and clear negative effect on Shannon's ant species diversity (Fig. 5a) and evenness (Fig. 5b) indices compared to both organic (G) and NPK (N) plantations. As for total ground insects, Shannon's ant species diversity and evenness indices are not clearly different between organic and NPK treatments.

Effect of number of pesticide applications on ant species diversity and evenness indices: Large differences are apparent in both Shannon's ant species diversity (Fig. 6a) and evenness (Fig. 6b) indices even between pesticide-free (OP) plantations and very low pesticide (1P) sprayed plantations. In highly pesticide sprayed plantations (3P), the reduction in both Shannon's ant species diversity and evenness indices is very drastic.

\section{Butterfly Bait Trap}

Nymphalid butterflies: Diversity: A total of 1,259 butterflies comprising 25 species from the family nymphalidae were collected using bait traps. The effect of treatment on the species diversity was observed to be the best fit model. Shannon's butterfly species diversity index $\left(H^{\prime}\right)$ is highest in organic $(G)$ plantations (Fig. 7) and clearly lower in pesticide (P) plantations. The role of treatment in determining Shannon's butterfly species diversity index $\left(\mathrm{H}^{\prime}\right)$ received further support from the next best model which included the additive effects of treatment and crops $(\triangle A I C=1.78)$. The data show a clear decrease in the nymphalid butterfly diversity in plantations sprayed with pesticides but patterns in nymphalid butterfly evenness are unclear.
All species data will be published separately as a Data Paper.

\section{DISCUSSION}

The intensification of agriculture has been associated with a substantial loss of biodiversity along with many important ecosystem services which include crop production, pest control, pollination and decomposition processes, and soil properties (Lal 1988; Daily 1997; Altieri 1999; Schläpfer et al. 1999; Tilman et al. 2002; Wilby \& Thomas 2002). The decline of biodiversity affects ecosystemfunctioningandyield(Russell1989;Daily1997). Local intensification may affect biological pest control (Russell1989; Matson etal.1997; Thies \& Tscharntke 1999; Östman et al. 2001; Symondson et al. 2002; Barbosa 2003; Donald 2004; Perfecto et al. 2004; Tylianakis et al. 2004), grassland production (Bullock et al. 2001; Loreau \& Hector 2001), pollination (Nabhan \& Buchmann 1997; Kremen et al. 2002; Klein et al. 2003a,b) and resistance to plant invasion (Lyons \& Schwartz 2001; Kennedy et al. 2002; Levine et al. 2004; Zavaleta \& Hulvey 2004). During the last decades, worldwide losses of biodiversity have occurred at an unprecedented scale and agricultural intensification has been a major driver of this global change (Matson et al. 1997; Tilman et al. 2001; Kremen et al. 2004). Hence, there is considerable concern that intensive modern agriculture is not compatible with the conservation of biodiversity (Robinson \& Sutherland 2002).

Organic farming is often thought of as a solution to the problems associated with biodiversity conservation in intensive agricultural landscapes. Our study shows that there is greater level of insect diversity (ground insects and butterflies) on organic plantations when compared to the conventional (chemical fertilizers and pesticidesprayed) plantations. Our study supports the contention that organic farming enhances biodiversity (Paoletti et al. 1992; Schönning \& Richardsdotter-Dirke 1996, Bignal \& McCracken 1996; Plachter 1999; Sutherland 2002a,b). Conventional agricultural pest-management practices often lead to altered food web structure and communities dominated by a few common species, which together contribute to pest outbreaks. Organic farming methods mitigate this ecological damage by promoting evenness among natural enemies (Crowder et al. 2010) which then contributes to a pest-predator balance. Hence, species evenness was considered an important response variable in the present study. Our results confirm the hypothesis that organic farming 
promotes species evenness of total ground insects.

The data generated and analyzed here clearly show that pesticide treatment has a significant negative effect on insect biodiversity as measured by Shannon's diversity and evenness indices. A comparative effect of treatment on mean Shannon's diversity index $\mathrm{H}^{\prime}$ for ground insects within each crop type clearly indicates that organic (and NPK) cardamom plantations have higher levels of biodiversity than corresponding coffee plantations. This is expected because cardamom is a native crop and grown under denser forest shade canopy than coffee. However, pesticide-treated cardamom plantations show the lowest levels of insect biodiversity. This can be explained by the very high levels (6-12 sprays per year) of pesticide use in conventional (chemical) cardamom plantations as compared to 1-2 sprays in conventional coffee plantations. There is no clearly observable difference in insect diversity between organic and NPK plantations. This result is probably because NPK treatment is limited to once per year and most of the plantations in the district show high plant (weed) diversity and good canopy cover. This produces a heavy build up of mulch and ground leaf litter, and this combined with heavy rainfall provides a good buffering capacity to the negative impacts of limited applications and quantities of fertilizers.

One of the interesting results of this study is that ants show a similar response to pesticide use as total insects but the magnitude of the effect is much greater: $50 \%$ reduction in diversity compared to $20 \%$ for total insects in organic versus pesticide-sprayed plantations. For total ground insects, a significant difference was observed between pesticide-free (OP) plantations and heavily pesticide-sprayed (3P) plantations, but not with low or moderate pesticide treatment. For ants, a significant difference was observed between pesticidefree (OP) plantations and even lightly pesticidesprayed (1P) plantations. These results indicate that ants are sensitive and rapid responders to plantation management practices and hence are good biological indicators (Campbell \& Tanton 1981; Majer 1983; Andersen 1990). This is especially significant in light of the fact that tropical regions support very high levels of insect diversity, which, combined with incomplete taxonomic work (Narendran 2001), makes identification a difficult task. This may account for the lacuna of other studies on total ground insects. Ants, on the other hand, have been extensively studied and their taxonomy is well understood (Narendran 2001). Moreover, ants are functionally important at different trophic levels (Alonso 2000) and play critical ecological roles in soil turnover and structure (Humphreys 1981; Lobry de Bruyn \& Conacher 1994), nutrient cycling (Levieux 1983; Lal 1988), plant protection, seed dispersal and seed predation (Ashton 1979; Beattie 1985; Christian 2001). Hence we propose, based on our results, that such future studies can be carried out more cost-effectively by simply considering patterns in ant diversity.

Despite the clear patterns in our results, we recognize that biodiversity in agricultural landscapes is affected by many factors other than the farming system. Fallow areas, such as field margins, habitat islands, hedgerows, natural pastures, wetlands, ponds and other small habitats are important refuges and source areas for many organisms. Maintenance of biodiversity in agricultural landscapes will depend on the preservation, restoration and management of such habitats (Corbett \& Rosenheim 1996; Stopes et al. 1995; Baudry et al. 2000; Tscharntke et al. 2002, 2005). Landscape structure and heterogeneity also contributes to biodiversity in agricultural areas (Marino \& Landis 1996; Fahrig \& Jonsen 1998; Krebs et al. 1999; Weibull et al. 2000; Berg 2002; Steffan-Dewenter et al. 2002; Benton et al. 2003; Dauber et al. 2003, Ricketts et al. 2004).

Our study shows that organic plantations support greater diversity of ground insects and nymphalid butterflies, and that ants are a good indicator taxon for ground insects. The number of pesticide applications was seen to have a strong effect on both ant and overall ground insect diversity. A better understanding of how species interact within a community and how communities function at the landscape level could be keys to the maintenance and utilization of biodiversity in agri-ecosystems. Therefore, there is a crucial need to conduct further similar research studies, at multiple spatial and temporal scales, especially from tropical regions dominated by agriculture.

\section{REFERENCES}

Alonso, L.E. (2000). Ants as indicators of diversity, pp. 80-88. In: Agosti, D., J.D. Majer, L.E. Alonso \& T.R. Schultz (eds.). Ants. Standard Methods for Measuring and Monitoring Biodiversity, Smithsonian Institution Press, Washington, DC, USA.

Altieri, M.A. (1999). The ecological role of biodiversity in agroecosystems. Agriculture, Ecosystems and Environment 74(13): 19-31; http://dx.doi.org/10.1016/S0167-8809(99)00028-6

Altieri, M.A. \& D.K. Letourneau (1984). Vegetation diversity and insect pest outbreaks. CRC Crit. Review of Plant Sciences 2(2): 131-169; http://dx.doi.org/10.1080/07352688409382193

Anand, M.O., J. Krishnaswamy \& A. Das. (2008). Proximity to forests drives bird conservation value of coffee plantations: implications for certification. Ecological Application 18(7): 1754-1763; http://dx.doi. org/10.1890/07-1545.1

Anderson, A.N. (1990). The use of ant communities to evaluate 
change in Australian terrestrial ecosystems: a review and a recipe. Proceedings of the Ecological Society of Australia 16: 347-357.

Andow, D.A. (1983). The extent of monoculture and insect pest populations: a comparison of wheat and cotton. Agriculture, Ecosystems and Environment 9: 25-35.

Anonymous (1985). Coffee Guide. Central Coffee Research Institute, Chikmagalur, India.

Ashton D. H. (1979). Seed harvesting by ants in forests of Eucalyptus rengans F. Muell. in central Victoria. Australian Journal of Ecology 4: 265-277.

Bali, A., A. Kumar \& J. Krishnaswamy (2007). The mammalian communities in coffee plantations around a protected area in the Western Ghats, India. Biological Conservation 139(1-2): 93-102; http://dx.doi.org/10.1016/j.biocon.2007.06.017

Barbosa, P. (2003). Conservation Biological Control. Academic Press, San Diego, USA.

Baudry, J., F. Burel, C. Thenail \& D. Le Coeur (2000). A holistic landscape ecology study of the interactions between activities and ecological patterns in Brittany, France. Landscape and Urban Planning 50(1-3): 119-128; http://dx.doi.org/10.1016/S0169-2046(00)00084-0

Beattie, A.J., (1985). The Evolutionary Ecology of Ant-Plant Mutualisms Cambridge University Press, New York, USA.

Bengtsson, J., J. Ahnstrom \& A.C. Weibull (2005). The effects of organic agriculture on biodiversity and abundance: a meta-analysis. Journal of Applied Ecology 42(2): 261-269; http://dx.doi.org/10.1111/ j.1365-2664.2005.01005.x

Benton, T.G., D.M. Bryant, L. Cole \& H.Q.P. Crick (2002). Linking agricultural practice to insect and bird populations: a historical study over three decades. Journal of Applied Ecology 39(4): 673687; http://dx.doi.org/10.1046/j.1365-2664.2002.00745.x

Benton, T.G., J.A. Vickery \& J.D. Wilson (2003). Farmland biodiversity: is habitat heterogeneity the key? Trends in Ecology and Evolution 18(4): 182-188; http://dx.doi.org/10.1016/S0169-5347(03)00011-9

Berg, A.. (2002). Composition and diversity of bird communities in Swedish farmland-forest mosaic landscapes. Bird Study 49(2): 153165; http://dx.doi.org/10.1080/00063650209461260

Bignal, E.M. \& D.I. McCracken (1996). Low-intensity farming systems in the conservation of the countryside. Journal of Applied Ecology 33(3): 413-424.

Bullock, J.M., R.F. Pywell, M.J.W. Burke \& K.J. Walker (2001). Restoration of biodiversity enhances agricultural production Ecological Letters 4(3): 185-189; http://dx.doi.org/10.1046/j.14610248.2001.00215.x

Burnham, K.P \& D.R. Anderson (2002). Model Selection and Multimodel Inference: A Practical Information-Theoretic Approach 2nd Edition. Springer-Verlag.

Campbell, A.J. \& M.T. Tanton (1981) Effects of fire on the invertebrate fauna of soil and litter of a eucalypt forest, pp. 215-241. In: Gill, A.M., R.H. Groves \& I.R. Noble (eds.). Fire and the Australian Biota. Australian Academy of Sciences, Canberra, Australia.

Christian, C.E. (2001). Consequences of a biological invasion reveal the importance of mutualism for plant communities. Nature 413: 635-639; http://dx.doi.org/10.1038/35098093

Corbett, A. \& J.A. Rosenheim (1996). Impact of a natural enemy overwintering refuge and its interaction with the surrounding landscape. Ecological Entomology 21(2): 155-164; http://dx.doi. org/10.1111/j.1365-2311.1996.tb01182.x

Crowder, D.W., T.D. Northfield, M.R. Strand \& W.E. Snyder (2010) Organic agriculture promotes evenness and natural pest control. Nature Letters 466: 109-112; http://dx.doi.org/10.1038/ nature09183

Daily, G.C. (1997). Nature's Services: Social Dependence on Natural Ecosystems. Island Press, Washington, DC, USA.

Dauber, J., M. Mirsch, D. Simmering, R. Waldhardt, A. Otte \& V. Wolters (2003). Landscape structure as an indicator of biodiversity: matrix effects on species richness. Agriculture, Ecosystems and Environment 98: 321-329; http://dx.doi.org/10.1016/S01678809(03)00092-6

de Bruyn, L. \& L.A. Conacher (1994). The bioturbation activity of ants in agricultural and naturally vegetated habitats in semi-arid environments. Australian Journal of Soil Research 32(3): 555-570; http://dx.doi.org/10.1071/SR9940555

Dolia, J., M.S. Devy, N.A. Aravind \& A. Kumar (2007). Adult butterfly communities in coffee plantations around a protected area in the Western Ghats, India. Animal Conservation 11(1): 26-34; http:// dx.doi.org/10.1111/j.1469-1795.2007.00143.x

Donald, P.F. (2004). Biodiversity impacts of some agricultural commodity production systems. Conservation Biology 18(1): 1738; http://dx.doi.org/10.1111/j.1523-1739.2004.01803.x

Fahrig, L. \& I. Jonsen (1998). Effect of habitat patch characteristics on abundance and diversity of insects in an agricultural landscape. Ecosystems 1(2): 197-205; http://dx.doi.org/10.1007/ s100219900015

Fuller, R.J., R.D. Gregory, D.W. Gibbons, J.H. Marchant, J.D. Wilson, S.R. Baillie \& N. Carter (1995). Population declines and range contractions among lowland farmland birds in Britain. Conservation Biology 9(6): 1425-1441; http://dx.doi.org/10.1046/j.15231739.1995.09061425.x

Horne, P.A. (2007). Carabids as potential indicators of sustainable farming systems. Australian Journal of Experimental Agriculture 47(4): 455-459; http://dx.doi.org/10.1071/EA05265

Humphreys, G.S., (1981). The rate of ant mounding and earthworm casting near Sydney. N.S.W. Search 12: 129-131.

Johnson, J.B. \& K.S. Omland (2004). Model selection in Ecology and Evolution. Trends in Ecology and Evolution 19(2): 101-108; http:// dx.doi.org/10.1016/j.tree.2003.10.013

Kehimkar, I. (2008). The Book of Indian Butterflies. BHNS, Oxford University Press, Mumbai.

Kennedy, T.A., S. Naeem, K.M. Howe, J.M.H. Knops, D. Tilman \& P. Reich (2002). Biodiversity as a barrier to ecological invasion. Nature 417: 636-638; http://dx.doi.org/10.1038/ nature00776

Klein, A., I. Steffan-Dewenter \& T. Tscharntke (2003a) Fruit set of highland coffee depends on the diversity of pollinating bees. Proceedings of the Royal Society of London 270(1518): 955961; http://dx.doi.org/10.1098/rspb.2002.2306

Klein, A., I. Steffan-Dewenter \& T. Tscharntke (2003b). Pollination of Coffea canephora in relation to local and regional agroforestry management. Journal of Applied Ecology 40(5): 837-845; http:// dx.doi.org/10.1046/j.1365-2664.2003.00847.x

Krebs, J.R., J.D. Wilson, R.B. Bradbury \& G.M. Siriwardena (1999) The second silent spring? Nature 400: 611-612; http://dx.doi. org/10.1038/23127

Kremen, C., N.M. Williams \& R.W. Thorp (2002). Crop pollination from native bees at risk from agricultural intensification. Proceedings of the National Academy of Sciences, USA 99: 16816-16821.

Kremen, C., N.M. Williams, R.L. Bugg, J.P. Fay \& R.W. Thorp (2004). The area requirement of an ecosystem service: crop pollination by native bee communities in California. Ecology Letters 7(11): 1109-1119; http://dx.doi.org/10.1111/j.1461-0248.2004.00662.x

Lal, R. (1988). Effects of macrofauna on soil properties in tropical ecosystems. Agriculture, Ecosystems, and Environment 24(1-3): 101-116; http://dx.doi.org/10.1016/0167-8809(88)90059-X

Levieux, J. (1983). The soil fauna of tropical savannas. IV. The ants, pp. 525-540. In: Bourliere, F. (ed.). Tropical Savannas. Elsevier, Amsterdam, Holland.

Levine, J.M., P.B. Adler \& S.G. Yelenik (2004). A meta-analysis of biotic resistance to exotic plant invasions. Ecology Letters 7(10): 975-989; http://dx.doi.org/10.1111/j.1461-0248.2004.00657.x

Loreau, M. \& A. Hector (2001). Partitioning selection and complementarity in biodiversity experiments. Nature 412: 72-76; http://dx.doi.org/10.1038/35083573

Lyons, G.K. \& M.W. Schwartz (2001). Rare species loss alters ecosystem function - invasion resistance. Ecology Letters 4(4): 358-365; http:// dx.doi.org/10.1046/j.1461-0248.2001.00235.x

MacFadyen, S., R.H. Gibson, A. Polaszek, R.J. Morris, P.G. Craze, R. Planque, W.O.C. Symondson \& J. Memmott (2009). Do differences in food web structure between organic and conventional farms 
affect the ecosystem service of pest control? Ecology Letters 12(3): 229-238; http://dx.doi.org/10.1111/j.1461-0248.2008.01279.x

Majer, J.D. (1983). Ants: bio-indicators of mine site rehabilitation, land-use, and land conservation. Environmental Management 7: 375-385.

Marino, P.C. \& D.A. Landis (1996). Effect of landscape structure on parasitoid diversity and parasitism in agroecosystems. Ecological Applications 6: 276-284.

Matson, P.A., W.J. Parton, A.G. Power \& M.J. Swift (1997). Agricultura intensification and ecosystem properties. Science 277(5325): 504509; http://dx.doi.org/10.1126/science.277.5325.504

Nabhan, G.P. \& S.L. Buchmann (1997). Services provided by pollination, pp. 133-150. In: Daily, G.C. (ed.). Nature's Services: Social Dependence on Natural Ecosystems. Island Press. Washington, DC, USA.

Narendran, T.C. (2001). Taxonomic entomology: Research and education in India. Current Science 81(5): 445-447.

Östman, Ö., B. Ekbom \& J. Bengtsson (2001). Farming practice and landscape heterogeneity influence biological control. Basic Applied Ecology 2(4): 365-371; http://dx.doi.org/10.1078/1439-179100072

Paoletti, M.G., D. Pimentel, B.R. Stinner \& D. Stinner (1992) Agroecosystem biodiversity: matching production and conservation biology. Agriculture, Ecosystem and Environment 40(1-4): 3-23; http://dx.doi.org/10.1016/0167-8809(92)90080-U

Perfecto, I., J.H. Vandermeer, G.L. Bautista, G.I. Nunez, R. Greenberg, \& P. Bichier (2004). Greater predation in shaded coffee farms: the role of resident neotropical birds. Ecology 85: 2677-2681; http:// dx.doi.org/10.1890/03-3145

Perfecto, I. \& J. Vandermeer (2010). The agroecological matrix as alternative to the land-sparing/agriculture intensification model. Proceedings of the National Academy of Science, USA 107(13) 5786-5791; http://dx.doi.org/10.1073/pnas.0905455107

Plachter, H. (1999). The contributions of cultural landscapes to nature conservation, pp. 93-115. In: Hajos, G. (ed.). Monument-SiteCultural Landscape Exemplified by the Wachau. Verlag Berger, Wien, Germany.

Quinn, G. \& M. Keough (2002). Experimental Design and Data Analysis for Biologists. Cambridge University Press.

Ricketts, T.H., G.C. Daily, P.R. Ehrlich \& C. D. Michener (2004). Economic value of tropical forest to coffee production. Proceedings of Nationa Academy of Sciences, USA 101(34): 12579-12582; http://dx.doi. org/10.1073/pnas.0405147101

Robinson, R.A. \& W.J. Sutherland (2002). Post-war changes in arable farming and biodiversity in Great Britain. Journal of Applied Ecology 39(1): 157-176; http://dx.doi.org/10.1046/j.13652664.2002.00695.x

Russell, E.P. (1989). Enemies hypothesis: a review of the effect of vegetational diversity on predatory insects and parasitoids. Environmental Entomology 18(4): 590-599.

Schläpfer, F., B. Schmid \& I. Seidl (1999). Expert estimates about effects of biodiversity on ecosystem processes and services. Oikos 84: 346-352.

Schönning, M. \& M. Richardsdotter-Dirke (1996). Organic and conventional agriculture: differences in biodiversity and food quality A literature review. Rapport 9304. Svenska Naturskyddsföreningen, Stockholm, Sweden.

Steffan-Dewenter, I., U. Münzenberg, C. Bürger, C. Thies \& T. Tscharntke (2002). Scale-dependent effects of landscape context on three pollinator guilds. Ecology 83: 1421-1432; http://dx.doi. org/10.1890/0012-9658(2002)083[1421:SDEOLC]2.0.CO;2
Stoate, C., N.D. Boatman, R.J. Borralho, C.R. Carvalho, G.R. de Snoo \& P. Eden (2001). Ecological impacts of arable intensification in Europe. Journal of Environmental Management 63(4): 337-365; http://dx.doi.org/10.1006/jema.2001.0473

Stopes, C., M. Measures, C. Smith \& L. Foster (1995). Hedgerow Management in Organic Farming. Biodiversity and Land Use: The Role of Organic Farming. Multitext, Barcelona, Spain.

Sutherland, W.J. (2002a). Restoring a sustainable countryside. Trends in Ecological Evolution 17(3): 148-150; http:/dx.doi.org/10.1016 / S0169-5347(01)02421-1

Sutherland, W.J. (2002b). Openness in management. Nature 418: 834835; http://dx.doi.org/10.1038/418834a

Symondson, W.O.C., K.D. Sunderland \& M.H. Greenstone (2002) Can generalist predators be effective biocontrol agents? Annual Review of Entomology 47: 561-594; http://dx.doi.org/10.1146/annurev. ento.47.091201.145240

Thies, C. \& T. Tscharntke (1999). Landscape structure and biological control in agroecosystems. Science 285(5429): 893-895; http:// dx.doi.org/10.1126/science.285.5429.893

Tilman, D., K.G. Cassman, P.A. Matson, R. Naylor \& S. Polasky (2002). Agricultural sustainability and intensive production practices. Nature 418: 671-677; http://dx.doi.org/10.1038/nature01014

Tilman, D., J. Fargione, B. Wolff, C. D’Antonio, A. Dobson \& R. Howarth (2001). Forecasting agriculturally driven global environmental change. Science 292(5515): 281-284; http://dx.doi. org/10.1126/science.1057544

Tscharntke, T., A.M. Klein, A. Kruess, I. Steffan-Dewenter \& C. Thies (2005). Landscape perspectives on agricultural intensification and biodiversity - ecosystem service management. Ecology Letters 8(8): 857-874; http://dx.doi.org/10.1111/j.1461-0248.2005.00782.x

Tscharntke, T., I. Steffan-Dewenter, A. Kruess \& C. Thies (2002). Contribution of small habitat fragments to conservation of insect communities of grassland-cropland landscapes. Ecological Applications 12: 354-363; http://dx.doi.org/10.1890/10510761(2002)012[0354:COSHFT]2.0.CO;2

Tylianakis, J.M., R.K. Didham \& S.D. Wratten (2004) Improved fitness of aphid parasitoids receiving resource subsidies. Ecology 85: 658666; http://dx.doi.org/10.1890/03-0222

World Bank Report (2010). http://siteresources.worldbank.org/ EXTANNREP2010/Resources/WorldBank:

Weibull, A.C., J. Bengtsson \& E. Nohlgren (2000). Diversity of butterflies in the agricultural landscape: the role of farming system and landscape heterogeneity. Ecography 23(6): 743-750; http:// dx.doi.org/10.1111/j.1600-0587.2000.tb00317.x

Wilby, A. \& M.B. Thomas (2002). Natural enemy diversity and pest control: patterns of pest emergence with agricultural intensification. Ecology Letters 5(3): 353-360; http://dx.doi. org/10.1046/j.1461-0248.2002.00331.x

Wilsey, B.J. \& H.W. Polley (2002). Reductions in grassland species evenness increase dicot seedling invasion and spittle bug infestation. Ecology Letters 5(5): 676-684; http://dx.doi.org/10.1046/j.14610248.2002.00372x

Wittebolle, L., M. Marzorati, L. Clement, A. Balloi, D. Daffonchio, K. Heylen, P. de Vos, W. Verstraete \& N. Boon (2009). Initial community evenness favours functionality under selective stress. Nature 458: 623-626; http://dx.doi.org/10.1038/nature07840

World Bank Report (2010). http://siteresources.worldbank.org/ EXTANNREP2010/Resources/WorldBank

Zavaleta, E.S. \& K.B. Hulvey (2004). Realistic species losses disproportionally reduce grassland resistance to biological invaders. Science 306(5699): 1175-1177; http://dx.doi.org/ 10.1126/science. 1102643 